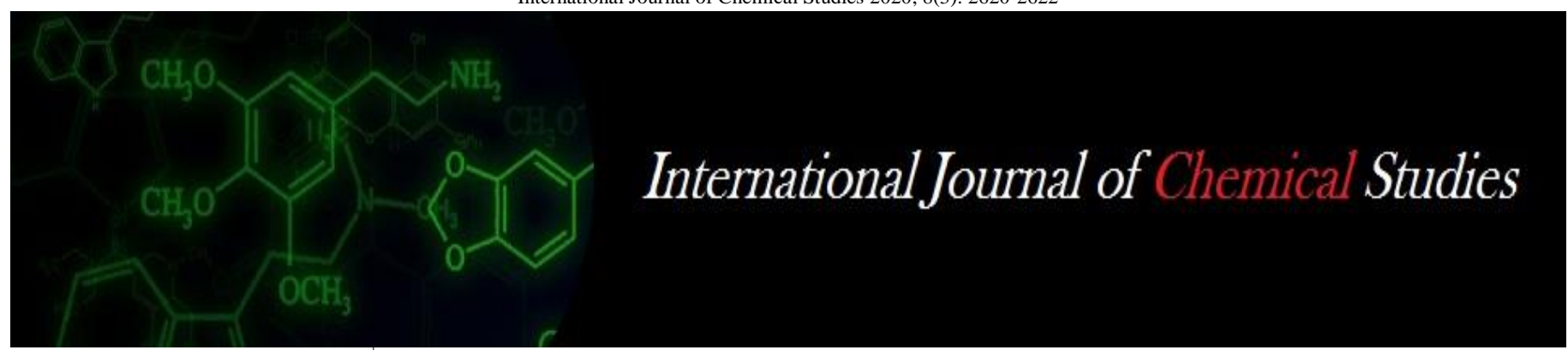

P-ISSN: 2349-8528

E-ISSN: 2321-4902

www.chemijournal.com

IJCS 2020; 8(3): 2620-2622

(C) 2020 IJCS

Received: 05-03-2020

Accepted: 10-04-2020

\section{Arunabha Pal}

Department of Agricultural

Chemistry and Soil Science,

Centurion University of

Technology and Management, Odisha, India

\section{Rahul Adhikary}

Department of Agricultural

Chemistry and Soil Science,

Centurion University of

Technology and Management,

Odisha, India

Susnata Kumar De

Department Soil and Water

Conservation, Bidhan Chandra

Krishi Viswavidyala, Mohanpur,

West Bengal, India

Milan Sardar

Department Soil and Water

Conservation, Bidhan Chandra

Krishi Viswavidyala, Mohanpur,

West Bengal, India
Corresponding Author:

Arunabha Pal

Department of Agricultural

Chemistry and Soil Science,

Centurion University of

Technology and Management,

Odisha, India

\section{Effect of different geotextile treatments in soil to increase the yield and yield attribute of capsicum (Capsicum annuum)}

\author{
Arunabha Pal, Rahul Adhikary, Susnata Kumar De and Milan Sardar
}

DOI: https://doi.org/10.22271/chemi.2020.v8.i3al.9608

\begin{abstract}
Geotextiles are textile like materials of natural product of eco-friendly and biodegradable in nature and act as useful ameliorative towards alleviating soil related constrains of crop production and improve soil structural performance. Application of suitable ameliorative thus necessitates for improving the growth of plant towards increasing the crop yield. In order to assess the effectiveness of various geotextiles on the improvement of growth of crop and enhancement of crop productivity, the present study has been undertaken. with five treatments combinations viz. T1 -non woven jute geotextile, T2 - non woven dry grasses geotextile, T3 - non woven coco coir geotextile, T4 - non woven banana leaf fibre geotextile and T5 - farmers practices (i.e. control). All geotextile materials @ 5 ton /ha were spread on the soil after final land preparation and before seedling or planting of capsicum. The results reveals that the jute fibre geotextile, dry grasses geotextile, coco coir geotextile, and banana leaf geotextile show much better performance than control (farmers practice) in respect of yields, yield attributes and growth parameters. Among the various geotextiles treatments, the jute fibre geotextile proves much superior performance for growth, yield and yield attributes of capsicum.
\end{abstract}

Keywords: Geotextile, yield of capsicum, yield attribute of capsicum, growth parameter of capsicum

\section{Introduction}

A geotextile is defined as any permeable textile material that is used with foundation, soil, rock, earth, etc. to increase stability and decrease wind and water erosion. A geotextile may be made of synthetic or natural fibers. Naturally occurring jute agro geo-textiles are eco-friendly and biodegradable products which act as surface cover materials and useful ameliorative to eliminate soil related constraints to crop production (Yong et al., 2000; Pain et al., 2013 and Adhikary et al. (2016) ${ }^{[9,1]}$. A geotextile is designed to be permeable to allow the flow of fluids through it or in it, and a geomembrane is designed to restrict the fluid flow (Mitchell et al., $2003)^{[8,15]}$. It plays a vital role in erosion control, increasing moisture holding capacity in soil, improving water uptake and drainage capacity (Ranganathan, 1994) ${ }^{[12]}$. Natural fiber geotextiles degrade to form organic mulch and help in quick establishment of vegetation. Different fibers will degrade at different rates e.g. coir geotextiles degrade in 2-3 years while jute degrades in 1-2 years (Adhikary et al., 2018 and Pal et al., 2020) ${ }^{[2,10]}$. Coir is therefore useful in situations where vegetation will take longer to establish, and jute is useful in low rainfall areas because it absorbs more moisture. Eco geotextile another similar soil conditioner, are equally effective in erosion control, stabilization of soil slops and increasing water retention capacity also improve crop productivity (Rajgopal and Ramkrishna, 1997) [13]. Current research suggests that the composition of the geotextile does not dramatically affect performance capabilities. But advantage of the product is that due to its biodegradable in nature, the materials are more stable than mulching, (Benik et al., 2003) ${ }^{[3]}$. A capsicum (Capsicum annuum) is a vegetable crop originates from South and Central America and members of the Solanaceae family, as are tomatoes, potatoes and eggplant. Plants are bushy, about $60-80 \mathrm{~cm}$ high and semi-perennials that are grown as annuals in commercial cultivation. They supply good levels of antioxidants and vitamin C. Capsicums are used in salads, baked and stuffed dishes, stews, stir-fries, salsa, pizzas and cheeses, pickles and for stuffing olives. They may also be used for producing paprika which is used for colouring foods, flavouring and in sauces. 


\section{Materials and Method}

The present study was carried out at the farmer's field in the and application of different geotextile treatment on soil to improve crop yield in humid and hot sub humid region, 2015 2016 at Gokna village near Baduria North 24 Parganas West Bengal. The land is situated at $22^{\circ} 71^{\prime} \mathrm{N}$ latitude, $88^{\circ} 75^{\prime} \mathrm{E}$ longitudes with and altitude at $5 \mathrm{~m}$ above the mean sea level. The climate is subtropical moist sub humid with mean annual temperature of $36.4^{\circ} \mathrm{C}$ to $14.4^{0} \mathrm{C}$ and mean annual rainfall of $1503 \mathrm{~mm}$ (Krishi Vigyan Kendra, Ashoknagar). The treatments details also described on (Table 1).

\section{Results and Discussion}

Vegetables play a major role in Indian agriculture by providing food, nutritional and economic security and more importantly, producing higher returns per unit area and time. In addition, vegetables have higher productivity, shorter maturity cycle, and high value and provide greater income leading to improved livelihoods.

\section{Yield and yield attributes of capsicums}

The results (Table 2) of pooled data of green capsicum yield recorded in 2015 and 2016 were showed variation with the application of various kinds of geotextile. The green capsicum yield were recorded as $20.85 \mathrm{q} / \mathrm{ha}, 19.12 \mathrm{q} / \mathrm{ha}, 17.48 \mathrm{q} / \mathrm{ha}$, $14.04 \mathrm{q} / \mathrm{ha}$ and $7.13 \mathrm{q} / \mathrm{ha}$ respectively in non-woven jute geotextile, dry grasses geotextile, coco- coir geotextile and banana leaf fiber geotextile and control (farmer's practice). The above results are in agreement with those reported by Khistaria et al. (1994) [7] and Divies et al. (2006) ${ }^{[5]}$. The maximum yield was recorded in non-woven Jute fibre geotextile. The response of yield over control due to each treatment were 13.72 tons/ha $(192.3 \%), 11.98$ tons/ha $(167.9 \%), 10.34$ tons/ha $(145 \%)$ and 6.90 tons/ha $(96.7 \%)$ respectively in non-woven jute geotextile, dry grasses, cococoir geotextile and banana leaf fibre geotextile. The yield of dry capsicum also showed similar result i.e. highest $(4.85$ tons/ha) and lowest (1.66 tons/ha), were recorded jute geotextile and control respectively. The above results are in agreement with those reported by Dutta and Chakraborty (1995) ${ }^{[6]}$. The number of green capsicum / plant pooled data also show that 4.62, 4.51, 4.25, 3.52 and 2.19 (Table 2) in respectively of in jute, dry grasses, coco- coir, banana leaf fiber geotextile and control (farmer's practice). The results of single green capsicum weight also showed similar trend of results as observed for the earlier. Wight of single green capsicum highest values (180.54 g) are observed for the treatments of jute geotextiles followed by the treatments of dry grasses $(169.5 \mathrm{~g})$, coco- coir geotextiles $(164.61 \mathrm{~g})$ and banana leaf fiber geotextiles $(159.35 \mathrm{~g})$. The above results are in agreement with those reported by Paza (2007) [11], Adhikary et al. (2018) ${ }^{[2]}$ and Adhikary et al. (2016) ${ }^{[1]}$.

\section{Physiological parameter of capsicum crop}

The result of physical parameters inducing growth of capsicum crop presented in (Table 3) by application of various geotextile. Although the difference of plant height and number of branch occurred due to application of each of the geotextiles, but better performance were observed with the application of jute geotextiles. The height of plant observes during harvesting were recorded $54.33 \mathrm{~cm} \& 49.46 \mathrm{~cm}$ in jute geotextile and control plot respectively and number of branches at the time of harvesting also recorded $12.8 \& 11.03$ in jute geotextile and control plot. The physiological growth of the capsicum crops due to application of geotextiles follows in the order of: jute > dry grasses > coco- coir > banana leaf fiber $>$ control. These results are highly indicative of the effect of geotextile on the physiological growth of the capsicum crop. The results of the dry matter production and crop growth rate influencing yield and growth of capsicum crop due to various geotextiles management are presented in (Table 3). The results reveal that total dry matter weight were found 357.46, 345.4, 334.96, 330.96 and $278.26 \mathrm{~g} /$ plant respectively in jute, dry grasses, coco- coir, banana leaf fiber geotextile and control. Response of dry matter production over control due to each treatment were $79.2 \mathrm{~g} / \mathrm{plant}$ (28.46\%), $67.13 \mathrm{~g} /$ plant $(24.12 \%), 56.13 \mathrm{~g} /$ plant $(20.37 \%)$, and $52.70 \mathrm{~g} /$ plant $(18.93 \%)$ respectively in jute, dry grasses, coco- coir, banana leaf fiber geotextile. Similarly crop growth rate was found as $3.57,3.45,3.35,3.31$ and $2.78 \mathrm{gm} /$ day in respectively of jute, dry grasses, coco- coir, banana leaf fiber geotextile and control plot. 50\% flowering \& $50 \%$ fruits day after sowing were found highest on jute geotextile 3.63 and 4.5 and lowest on farmers practice plot 2.56 and 3.86 respectively. The above results are in agreement with those reported by Dayal (1989) ${ }^{[4]}$ and Sharma et al. (2010) ${ }^{[14]}$.

Table 1: Experimental Details

\begin{tabular}{|c|c|}
\hline \multirow{5}{*}{ Treatment Details } & T1: Non woven jute fibre geotextile (5 ton+ NPK @ 60: 40: $40 \mathrm{~kg} / \mathrm{ha}$ ) \\
\hline & $\mathrm{T}_{2}$ : Non woven dry grasses fibre geotextile. (5 ton+ NPK @ 60: 40: $40 \mathrm{~kg} / \mathrm{ha}$ ) \\
\hline & T3: Non woven coco coir geotextile. (5 ton+ NPK @ 60: 40: 40 kg/ha) \\
\hline & T4: Non woven banana leaf fibre geotextile. (5 ton+ NPK @ 60: 40: $40 \mathrm{~kg} / \mathrm{ha}$ ) \\
\hline & T5: Control (farmer practice). (NPK @ 60: 40: $40 \mathrm{~kg} / \mathrm{ha}$ ) \\
\hline Plot size: & $36 \mathrm{sq} \mathrm{m}$ \\
\hline Design: & RBD \\
\hline Replication: & 3 \\
\hline Date of planting: & January $2^{\text {nd }} 2015$ \\
\hline
\end{tabular}

Table 2: Effects different Geotextile on Capsicum yield and yield attribute component

\begin{tabular}{|c|c|c|c|c|c|}
\hline Treatment & No. of Plant/ ha & $\begin{array}{c}\text { No. of Green } \\
\text { Capsicum /Plant }\end{array}$ & $\begin{array}{c}\text { Wt of single Green Capsicum } \\
\text { (gm) }\end{array}$ & $\begin{array}{c}\text { Green Capsicum } \\
\text { (tons/ha) }\end{array}$ & $\begin{array}{c}\text { Dry Capsicum } \\
\text { tons/ha) }\end{array}$ \\
\hline Jute & 25000.000 & 4.62 & 180.54 & 20.85 & 4.85 \\
\hline Dry grasses & 25000.000 & 4.51 & 169.54 & 19.12 & \\
\hline Coco coir & 25000.000 & 4.25 & 164.61 & 17.48 & \\
\hline Banana leaf fibre & 25000.000 & 3.52 & 159.35 & 14.04 & \\
\hline Control & 25000.000 & 2.19 & 130.51 & 7.04 & 3.26 \\
\hline SEm( \pm ( & & 0.01 & 0.34 & 0.08 & \\
\hline CD at 5\% & & 0.05 & 1.10 & 0.25 & 0.02 \\
\hline
\end{tabular}


Table 3: Effects different Geotextile on physiological parameter of Capsicum.

\begin{tabular}{|c|c|c|c|c|c|c|}
\hline Treatment & $\begin{array}{c}\text { No. of branch } \\
\text { at Harvesting }\end{array}$ & $\begin{array}{c}\text { Height of the plant } \\
\text { during Harvesting(cm) }\end{array}$ & $\begin{array}{c}\text { 50\% flowering } \\
\text { (DAS)/plant }\end{array}$ & $\begin{array}{c}\text { 50\% fruits } \\
\text { (DAS)/plant }\end{array}$ & $\begin{array}{c}\text { Dry Matter at } \\
\text { Harvesting(gm/plant) }\end{array}$ & $\begin{array}{c}\text { Crop Growth } \\
\text { Rate(gm/day) }\end{array}$ \\
\hline Jute & 12.80 & 54.43 & 3.63 & 4.50 & 357.46 & 3.57 \\
\hline Dry grasses & 12.33 & 50.88 & 3.30 & 4.33 & 345.40 & \\
\hline Coco coir & 12.06 & 50.10 & 3.00 & 4.16 & 334.96 & 3.45 \\
\hline Banana leaf fibre & 11.73 & 49.93 & 2.90 & 4.06 & 330.96 & \\
\hline Control & 11.03 & 49.46 & 2.56 & 3.86 & 278.26 & 2.31 \\
\hline SEm( \pm ) & 0.100 & 1.460 & 0.070 & 0.050 & 2.340 & 0.020 \\
\hline CD at 5\% & 0.330 & 4.750 & 0.220 & 0.180 & 7.630 & 0.080 \\
\hline
\end{tabular}

\section{Conclusion}

The results of present study lead to suggest that application of each of geotextiles increased growth and yield of capsicum crop. Used of different geotextiles in soil as soil conditioner in which jute geotextile was found to be most efficient to keep the soil in friable condition that helps to improve soil condition which helps to increase the yield.

\section{References}

1. Adhikary N, Disha A, Mahata AP, Pal A, Adhikary R, Sardar M et al. Journal of Soil and Water Conservation. 2016; 15(3):242-245.

2. Adhikary R, Ravi Sankar L. Use of geotextiles for improving crop productivity on groundnut in Inceptisols. International Journal of Chemical Studies. 2018; 6(5):2673-2678.

3. Benik SR, Wilson BN, Biesboer DD, Hansen B, Stenlund D. Evaluation of erosion control products using natural rainfall events. Journal of Soil and Water Conservation. 2003; 58(2):98-104.

4. Dayal D. Response of summer groundnut to mulching under varying irrigation regime, Journal of GroundnutNews. 1989; 2(1):5.

5. Divies K, Fullen MA. A pilot project on the potential contribution of pulm geotextile to soil conservation, Earth surface processes and landforms (In press), 2006.

6. Dutta T, Chakraborty T. Effect of organic manures and subabul leaf mulching under varying levels of fertility on growth and yield of potato and weed biomass. Indian Journal of Agron. 1995; 40(1):140-142.

7. Khistaria MK, Patel JS, Paida VJ, Patel JC. Effect of different mulches on the yield of groundnut under rainfed conditions, Gujarat Agricultural University Research Journal. 1994; 20(1):139-140.

8. Mitchell DJ, Barton AP, Fullen MA, Hocking TJ, WuBo Z, Zheng Y. Field studies of the effects of jute geotextiles on runoff and erosion in Shropshire, UK. Soil Use and Management. 2003; 19(2):182-184.

9. Pain, Debabrata De, Susanta Kumar, Tarafdar PK, Pal Arunabha, Mahata et al. Efficient use of geotextiles as soil conditioner to increase potato productivity on inceptisols of West Bengal. Journal of Soil and Conservation. 2013; 12(2):103-107.

10. Pal A, Adhikary R, Bera M, De SK, Sardar M. Application of different geotextile in soil to improve the soil health in humid and hot sub humid region of West Bengal. International Journal of Current Microbiology and Applied Sciences, 2020, 9(06).

11. Paza A. The fertilization of potato with cash crops and straw. Framenta Agronomical. 2007; 24(40):100-105.

12. Ranganathan SR. Development potential of jute geotextiles. Journal of Geotextiles and Geomembrance. 1994; 13(6-7):421-433.
13. Rajagopal K, Ramakrishna S. Degradation behaviour of coco geotextiles with in clay soils. Proc. Of Asian Regional Conf. on Geosynthesis, 1997, 25-29.

14. Sharma VAK. Dekshinamurtic Curr. Sci. 1971; 40:35.

15. Mitchell DJ, Barton AP, Fullen MA, Hocking TJ, WuBo Z, Zheng Y. Field studies of the effects of jute geotextiles on runoff and erosion in Shropshire, UK. Soil Use and Management. 2003; 19(2):182-184. 